\title{
IMPLEMENTASI CORPORATE SOCIAL RESPONSIBILITY PT RIAU CRUMB RUBBER FACTORY TERHADAP MASYARAKAT KELURAHAN SRI MERANTI KOTA PEKANBARU
}

\author{
Andrew Shandy Utama \\ Fakultas Hukum Universitas Lancang Kuning \\ +6285271864416/andrew.fh.unilak@gmail.com \\ Rizana \\ Fakultas Hukum Universitas Lancang Kuning \\ +6282174237080/rizana_ependi@yahoo.com
}

\begin{abstract}
A company that carries out its business activities in the field and/or related to natural resources is obliged to carry out its Corporate Social Responsibility (CSR). This research was conducted at PT Riau Crumb Rubber Factory which is located in Sri Meranti Village. Raw rubber production activities into semi-finished rubbers have been routinely generating pollution for the environment and society, such as air pollution and water pollution. The problem is how the implementation of CSR PT Riau Crumb Rubber Factory to the community of Sri Meranti Village in Pekanbaru City? What are the obstacles and the legal effort based on Riau Province Regional Regulation Number 6 Year 2012? This research is a sociological law research. Source of data used in this research is primary data and secondary data. Data collection techniques used in this study are observation, interview, and literature study. Data analysis technique used in this research is qualitative analysis. The result of this research is PT Riau Crumb Rubber Factory has implemented CSR, but has not fulfilled the expectation the community of Sri Meranti Village because it is not comparable with the pollution and environmental damage caused by the company's operational activities. The obstacle from the company side is the limited budget of CSR funds owned by PT Riau Crumb Rubber Factory to be able to meet all the needs of the community, while from the community side is the lack of legal knowledge of the community of Sri Meranti Village about CSR. The legal effort is that if PT Riau Crumb Rubber Factory does not implement CSR, the community of Sri Meranti Village can convey their aspirations to the DPRD of Riau Province for the company to be recommended to get administrative sanction from the government, such as the suspension of operational license of the company.
\end{abstract}

Keywords: Corporate Social Responsibility; PT Riau Crumb Rubber Factory; Sri Meranti Community 


\begin{abstract}
Abstrak
Perusahaan yang menjalankan kegiatan usahanya di bidang dan/atau berkaitan dengan sumber daya alam wajib melaksanakan tanggung jawab sosial dan lingkungan (Corporate Social Responsibility/CSR). Penelitian ini dilaksanakan pada PT Riau Crumb Rubber Factory yang berkedudukan di Kelurahan Sri Meranti. Kegiatan produksi karet mentah menjadi karet setengah jadi yang berlangsung secara rutin telah menyebabkan berbagai polusi bagi lingkungan dan masyarakat, seperti polusi udara dan polusi air. Permasalahannya adalah bagaimanakah implementasi CSR PT Riau Crumb Rubber Factory terhadap masyarakat Kelurahan Sri Meranti Kota Pekanbaru? Bagaimanakah hambatannya dan upaya hukumnya berdasarkan Peraturan Daerah Provinsi Riau Nomor 6 Tahun 2012? Penelitian ini adalah penelitian hukum sosiologis. Sumber data yang digunakan dalam penelitian ini adalah data primer dan data sekunder. Teknik pengumpulan data yang digunakan dalam penelitian ini adalah observasi, wawancara, dan studi kepustakaan. Teknik analisis data yang digunakan dalam penelitian ini adalah analisis kualitatif. Hasil dari penelitian ini adalah PT Riau Crumb Rubber Factory telah melaksanakan CSR, namun belum memenuhi harapan masyarakat Kelurahan Sri Meranti karena tidak sebanding dengan polusi dan kerusakan lingkungan yang diakibatkan oleh kegiatan operasional perusahaan. Hambatannya dari sisi perusahaan adalah terbatasnya anggaran dana CSR yang dimiliki oleh PT Riau Crumb Rubber Factory untuk dapat memenuhi semua kebutuhan masyarakat, sedangkan dari sisi masyarakat adalah minimnya pengetahuan hukum masyarakat Kelurahan Sri Meranti mengenai CSR. Upaya hukumnya adalah apabila PT Riau Crumb Rubber Factory tidak melaksanakan CSR maka masyarakat Kelurahan Sri Meranti dapat menyampaikan aspirasinya kepada DPRD Provinsi Riau agar perusahaan tersebut direkomendasikan mendapat sanksi administratif oleh pemerintah.
\end{abstract}

Kata Kunci: Tanggungjawab Sosial Perusahaan; PT Riau Crumb Rubber; Masyarakat Sri Meranti

\title{
A. PENDAHULUAN
}

Menurut Undang-Undang Nomor 40 Tahun 2007, perseroan terbatas (perusahaan) adalah badan hukum yang merupakan persekutuan modal, didirikan berdasarkan perjanjian, melakukan kegiatan usaha dengan modal dasar yang seluruhnya terbagi dalam saham, dan memenuhi persyaratan yang ditetapkan oleh undang-undang dan peraturan pelaksanaannya. Keberadaan perusahaan telah menjadi institusi bisnis yang dominan. Perusahaan telah memberikan pengaruh bagi pembangunan ekonomi nasional. Aktivitas perusahaan secara nyata telah memberikan lapangan kerja, memberikan produk barang maupun jasa yang diperlukan untuk kehidupan masyarakat, meningkatkan pembangunan ekonomi berkelanjutan, meningkatkan kapasitas dan kemampuan teknologi nasional, serta 
mewujudkan kesejahteraan masyarakat dalam suatu sistem perekonomian yang berdaya saing.

Berbagai peraturan telah dibuat terkait dengan kelembagaan dan aktivitas bisnis perusahaan, seperti Undang-Undang Nomor 40 Tahun 2007 tentang Perseroan Terbatas. Secara prinsip, perusahaan adalah lembaga privat yang didirikan dengan modal dan tujuan utamanya mencari keuntungan. Hal ini yang seringkali menjadi alasan perusahaan untuk melakukan aktivitas bisnis tanpa memperhatikan nilai moral dan etika bisnis, sehingga operasional perusahaan menimbulkan berbagai persoalan sosial seperti ketimpangan sosial, menimbulkan dampak lingkungan yang tidak nyaman, pemborosan penggunaan sumber daya alam, ketidaksetaraan kedudukan antara produsen dan konsumen, serta ketidaksamaan posisi tawar antara perusahaan dan karyawan. Bahkan, tanpa disadari perusahaan telah melakukan pencelaan terhadap harkat dan martabat kemanusiaan dan lingkungan hidup secara luas.

Dari sisi yang lain, interaksi antara perusahaan dengan masyarakat secara sosial semakin lekat. Perusahaan telah masuk dan mempengaruhi semua lini kehidupan masyarakat. Perusahaan, selain sebagai institusi bisnis, juga telah menjadi bagian dari warga negara (corporate citizenship) yang terlibat langsung dengan dinamika masyarakat. Keberlanjutan bisnis perusahaan juga sangat bergantung pada kondisi ekonomi dan kualitas kehidupan masyarakat. Perusahaan tidak boleh hanya mencari keuntungan semata, tetapi juga harus ikut serta memperhatikan kelestarian lingkungan hidup dan peduli pada persoalan sosial yang dihadapi masyarakat.

Secara umum, prinsip-prinsip yang berlaku dalam kegiatan bisnis yang baik sesungguhnya tidak bisa dilepaskan dari kehidupan kita sebagai manusia pada umumnya. Prinsip-prinsip itu sangat erat terkait dengan sistem nilai yang dianut oleh masyarakat. Prinsip-prinsip dalam etika bisnis antara lain yaitu prinsip otonomi, prinsip kejujuran, prinsip berbuat baik (beneficence) dan tidak berbuat jahat (non-maleficence), prinsip keadilan, serta prinsip hormat kepada diri sendiri (Khairandy, 2009: 132-134).

Tanggung jawab sosial pada dasarnya merupakan derivasi dari etika bisnis. Etika bisnis ini timbul dari adanya interaksi bisnis antara manusia yang saling melengkapi pemenuhan kebutuhan antara yang satu dengan yang lain sebagai akibat dari kompleksitas kebutuhan manusia yang kian berkembang dan tidak terbatas. Etika bisnis dapat menjembatani kepentingan antara kebutuhan perseroan dengan masyarakat sosial, baik yang terkena dampak langsung maupun tidak langsung dari operasional perseroan tersebut (Fahmi, 2015: 37). Jika suatu perusahaan tidak menerapkan etika bisnis, maka taruhannya adalah jatuhnya reputasi perusahaan dan berkurangnya kepercayaan dari stakeholders. Kedua hal tersebut merupakan faktor yang sangat penting untuk tetap menjaga kelangsungan 
kegiatan usaha perusahaan. Hal ini sejalan dengan pelaksanaan tanggung jawab sosial perusahaan yang dapat menjaga kinerja perusahaan untuk jangka panjang.

Dilihat dari sudut pandang hukum bisnis, setidaknya ada dua tanggung jawab yang harus diajarkan dalam etika bisnis, yaitu tanggung jawab hukum (legal responsibility) dan tanggung jawab sosial (social responsibility). Tanggung jawab hukum meliputi aspek perdata (civil liability) dan aspek pidana (crime liability), sedangkan tanggung jawab sosial dibangun di atas landasan norma moral yang berlaku di masyarakat (Khairandy, 2009: 138). Pada tahun 1990-an, tanggung jawab sosial perusahaan (corporate social responsibility) menjadi suatu gagasan yang menyita perhatian berbagai kalangan, mulai dari kalangan akademis, lembaga swadaya masyarakat, hingga para pelaku bisnis (Khairandy, 2009: 129).

Penerapan corporate social responsibility oleh perusahaan berarti bahwa perusahaan bukan hanya merupakan entitas bisnis yang hanya berusaha mencari keuntungan semata, tetapi perusahaan itu merupakan satu kesatuan dengan keadaan ekonomi, sosial, dan lingkungan tempat perusahaan tersebut beroperasi (Khairandy, 2009: 138). Corporate social responsibility adalah tanggung jawab yang melekat pada setiap perusahaan untuk tetap menciptakan hubungan yang serasi, seimbang, dan sesuai dengan lingkungan, nilai, norma, dan budaya masyarakat setempat, sehingga setiap perusahaan berkewajiban melaksanakan corporate social responsibility bagi masyarakat yang bertempat tinggal di sekitar lokasi perusahaan, termasuk PT Riau Crumb Rubber Factory yang berkedudukan di Kelurahan Sri Meranti Kota Pekanbaru.

PT Riau Crumb Rubber Factory adalah pabrik pengolahan bahan karet mentah menjadi bahan karet setengah jadi untuk bahan baku industri. Namun, kegiatan produksi pengolahan bahan karet mentah menjadi bahan karet setengah jadi yang berlangsung secara terus-menerus di perusahaan tersebut telah menyebabkan berbagai polusi yang berdampak bagi lingkungan dan masyarakat, seperti polusi udara dan polusi air. Pengolahan bahan karet mentah tersebut menimbulkan bau busuk yang menyengat yang mengganggu pernapasan masyarakat yang bertempat tinggal di sekitar lokasi perusahaan. Selain itu, Sungai Siak yang merupakan sumber air utama bagi masyarakat di sana airnya juga telah tercemar oleh limbah pabrik.

Pada Pasal 74 Undang-Undang Nomor 40 Tahun 2007 tentang Perseroan Terbatas ditegaskan bahwa perseroan yang menjalankan kegiatan usahanya di bidang dan/atau berkaitan dengan sumber daya alam wajib melaksanakan tanggung jawab sosial dan lingkungan. Ketentuan ini bertujuan untuk tetap menciptakan hubungan perseroan yang serasi, seimbang, dan sesuai dengan lingkungan, nilai, norma, dan budaya masyarakat setempat.

Apabila mengacu pada ketentuan di dalam Undang-Undang Nomor 40 Tahun 2007 di atas, maka corporate social responsibility telah ditetapkan sebagai kewajiban hukum, bukan lagi sebagai kewajiban moral yang pelaksanaannya bersifat sukarela. 
Hal ini bertujuan untuk melindungi kepentingan masyarakat yang bertempat tinggal di sekitar lokasi perusahaan dan untuk menjaga kelestarian lingkungan tempat perusahaan beroperasi. Apabila ada perusahaan yang tidak melaksanakan corporate social responsibility, maka akan dikenakan sanksi sesuai dengan ketentuan peraturan perundang-undangan yang berlaku. Akan tetapi, kelemahan undangundang tersebut adalah bahwa corporate social responsibility hanya diwajibkan terbatas pada perusahaan yang menjalankan kegiatan usahanya di bidang sumber daya alam dan/atau berkaitan dengan sumber daya alam.

Diundangkannya Peraturan Daerah Provinsi Riau Nomor 6 Tahun 2012 tentang Tanggung Jawab Sosial Perusahaan di Provinsi Riau semakin memperkokoh landasan hukum pelaksanaan Corporate Social Responsibility bagi perusahaanperusahaan yang beroperasi di wilayah Provinsi Riau. Pada Pasal 10 Peraturan Daerah Provinsi Riau Nomor 6 Tahun 2012 disebutkan bahwa program tanggung jawab sosial perusahaan dapat berbentuk pemberdayaan masyarakat dan/atau kemitraan dan bina lingkungan dan/atau investasi dan/atau sumbangan/donasi, dan/atau promosi. Selanjutnya, pada Pasal 11 peraturan daerah tersebut juga disebutkan bahwa bidang kerja tanggung jawab sosial perusahaan dapat dijalankan pada bidang pendidikan, kesehatan, infrastruktur, olahraga dan seni budaya, sosial dan keagamaan, pelestarian lingkungan hidup, usaha ekonomi kerakyatan, pemberdayaan masyarakat adat, serta bidang kerja lainnya yang secara nyata memberikan dampak peningkatan kualitas masyarakat.

Dari observasi awal yang dilakukan, menurut Ketua RW 02 Kelurahan Sri Meranti, Corporate Social Responsibility yang dilaksanakan oleh PT Riau Crumb Rubber Factory sangat minim dirasakan oleh masyarakat. Hal ini tidak sebanding dengan polusi dan kerusakan lingkungan yang diakibatkan oleh kegiatan operasional perusahaan tersebut, yang dampaknya dirasakan langsung sehari-hari oleh masyarakat. Oleh karenanya, berdasarkan uraian di atas, maka rumusan masalah yang menjadi pembahasan dalam penelitian ini adalah sebagai berikut:

1. Bagaimanakah implementasi Corporate Social Responsibility PT Riau Crumb Rubber Factory terhadap masyarakat Kelurahan Sri Meranti Kota Pekanbaru?

2. Bagaimanakah hambatan-hambatan dalam implementasi Corporate Social Responsibility PT Riau Crumb Rubber Factory terhadap masyarakat Kelurahan Sri Meranti Kota Pekanbaru?

3. Bagaimanakah upaya hukum terhadap hambatan-hambatan dalam implementasi Corporate Social Responsibility PT Riau Crumb Rubber Factory terhadap masyarakat Kelurahan Sri Meranti berdasarkan Peraturan Daerah Provinsi Riau Nomor 6 Tahun 2012 tentang Tanggung Jawab Sosial Perusahaan di Provinsi Riau?

\section{B. METODOLOGI PENELITIAN}

Penelitian ini adalah penelitian hukum sosiologis mengenai implementasi Corporate Social Responsibility PT Riau Crumb Rubber Factory terhadap masyarakat 
Kelurahan Sri Meranti Kota Pekanbaru berdasarkan Peraturan Daerah Provinsi Riau Nomor 6 Tahun 2012 tentang Tanggung Jawab Sosial Perusahaan di Provinsi Riau. Sumber data yang digunakan dalam penelitian ini adalah data primer dan data sekunder. Data primer diperoleh langsung dari hasil observasi dan wawancara, sedangkan data sekunder diperoleh dari jurnal ilmiah, literatur hukum, dan peraturan perundang-undangan. Teknik pengumpulan data yang digunakan dalam penelitian ini adalah observasi, wawancara, dan studi kepustakaan. Teknik analisis data yang digunakan dalam penelitian ini adalah analisis kualitatif.

\section{PEMBAHASAN}

\section{KERANGKA TEORI}

The World Business Council for Suistainable Development menjelaskan bahwa Corporate Social Rsponsibility dikonsepkan sebagai komitmen dari dunia usaha untuk terus-menerus bertindak secara etis, beroperasi secara legal, dan berkontribusi untuk peningkatan ekonomi bersamaan dengan peningkatan kualitas hidup dari karyawan dan keluarganya, sekaligus peningkatan kualitas komunitas lokal dan masyarakat secara luas. Menurut Salim (2016: 107-108), konsep Corporate Social Responsibility bukan hanya sebuah komitmen, melainkan sebuah kewajiban. Corporate Social Responsibility adalah kewajiban kemasyarakatan yang harus ditanggung atau dilakukan oleh perusahaan untuk meningkatkan kualitas dan kuantitas masyarakat yang berada di sekitar lingkungan perusahaan maupun di luar lingkungan perusahaan.

Teori mengenai Corporate Social Responsibility dapat diklasifikasikan menjadi empat kelompok, yaitu instrumental theory, political theory, integrative theory, dan ethical theory. Pertama, instrumental theory, atau yang lebih dikenal dengan shareholder theory. Menurut teori ini, Corporate Social Responsibility hanya sebagai alat untuk mencapai tujuan ekonomi perusahaan, memperoleh keuntungan. Kedua, political theory, atau yang lebih dikenal dengan corporate constitutionalism atau corporate citizenship. Menurut teori ini, perusahaan tidak saja secara moral dan secara hukum bertanggung jawab atas aktivitasnya, tetapi juga tanggung jawab sosialnya sebagai warga negara yang baik. Ketiga, integrative theory. Menurut teori ini, perusahaan harus mengintegrasikan aktivitasnya dengan kebutuhan masyarakat, karena Corporate Social Responsibility tidak lagi dianggap sebagai beban perusahaan, tetapi menjadi strategi perusahaan untuk mencapai tujuan bisnisnya. Keempat, ethical theory, atau yang lebih dikenal dengan stakeholder theory. Menurut teori ini, hubungan antara perusahaan dan masyarakat terkait dengan nilai-nilai etika, sehingga konsekuensinya perusahaan harus melaksanakan Corporate Social Responsibility sebagai kewajiban etika melampaui pertimbanganpertimbangan lainnya (Santoso, 2010: 214-216).

\section{TINJAUAN PUSTAKA}

Berbagai literatur tentang hukum perusahaan yang membahas mengenai Corporate Social Responsibility telah banyak ditulis oleh para ahli. Salah satunya 
yaitu yang terdapat dalam buku "Perseroan Terbatas; Doktrin, Peraturan Perundangundangan, dan Yurisprudensi" karangan Ridwan Khairandy. Dalam bukunya tersebut, Ridwan Khairandy membahas corporate social responsibility mulai dari awal mula konsep Corporate Social Responsibility, makna dan ruang lingkup corporate social responsibility dewasa ini, serta etika bisnis dan tanggung jawab sosial dalam kegiatan perusahaan (Khairandy, 2009: 134-143). Selain itu, di dalam buku "Status Badan Hukum, Prinsip-prinsip, dan Tanggung Jawab Sosial Perseroan Terbatas" karangan Habib Adjie juga terdapat pembahasan mengenai Corporate Social Responsibility mulai dari arti tanggung jawab sosial perusahaan, ruang lingkup tanggung jawab sosial perusahaan, serta hubungan tanggung jawab sosial perusahaan dengan etika bisnis (Adjie, 2008: 61-71). Akan tetapi, di dalam kedua buku tersebut tidak ada membahas mengenai implementasi Corporate Social Responsibility terhadap masyarakat yang bertempat tinggal di sekitar lokasi perusahaan.

Mengenai implementasi corporate social responsibility terhadap masyarakat, buku "Corporate Social Responsibility" karangan Hendrik Budi Untung ada menjelaskannya. Dalam bukunya tersebut, Hendrik Budi Untung menjelaskan mengenai implementasi Corporate Social Responsibility PT Kaltim Prima Coal terhadap masyarakat Kecamatan Rantau Pulung di Kabupaten Kutai Timur. Dijelaskannya bahwa program Corporate Social Responsibility yang dijalankan oleh PT Kaltim Prima Coal mampu meningkatkan perekonomian dan kesejahteraan masyarakat, terutama bagi masyarakat yang berprofesi sebagai petani buah-buahan (Untung, 2009: 3).

Pada Jurnal Hukum RESPUBLICA Volume 7 Nomor 1 Tahun 2007, Zulfikar Jayakusuma menulis dengan judul "Tanggung Jawab Sosial Perusahaan Transnasional Pertambangan Minyak terhadap Masyarakat Lokal (Perspektif Hak Asasi Manusia)". Menurutnya, mengintegrasikan tanggung jawab sosial perusahaan dengan hak asasi manusia merupakan suatu parameter untuk mengukur pelaksanaan tanggung jawab sosial perusahaan terhadap masyarakat lokal (Jayakusuma, 2007: 111). Pada jurnal yang sama, Yetti menulis dengan judul "Tanggung Jawab Perusahaan terhadap Sosial dan Lingkungan Berdasarkan UndangUndang Nomor 40 Tahun 2007 tentang Perseroan Terbatas". Menurutnya, program corporate social responsibility sebagai bentuk solidaritas sosial perusahaan bukan hanya berguna bagi masyarakat, melainkan juga sangat bermanfaat untuk membentuk citra perusahaan apabila dikemas dengan publikasi yang tepat (Yetti, 2007: 116).

Lalu, pada Jurnal Hukum YUSTISIA Edisi 77 Tahun XX Tahun 2009, Sentosa Sembiring menulis dengan judul "Tanggung Jawab Sosial dan Lingkungan (Corporate Social and Environment Responsibilities) dalam Perspektif Hukum Perusahaan". Menurutnya, penerapan Corporate Social Responsibility harus diintegrasikan ke seluruh aktivitas perusahaan yang mencakup tujuh isu pokok, yaitu pengembangan 
masyarakat, konsumen, praktik kegiatan institusi yang sehat, lingkungan, ketenagakerjaan, hak asasi manusia, dan organisasi pemerintahan. Substansi keberadaan Corporate Social Responsibility adalah dalam rangka memperkuat keberlanjutan perusahaan dengan jalan membangun kerja sama dengan pemangku kepentingan melalui program-program pengembangan masyarakat di sekitarnya (Sembiring, 2009: 70-71).

Selanjutnya, pada Jurnal Hukum RESPUBLICA Volume 8 Nomor 2 Tahun 2009, Ferdi menulis dengan judul "Aspek Hukum Internasional dalam Pengaturan Tanggung Jawab Sosial Perusahaan (Corporate Social Responsibility)". Menurutnya, tanggung jawab sosial perusahaan dilatarbelakangi oleh konsep suistainable development (pembangunan berkelanjutan) yang dirumuskan dalam konferensi internasional di Stockholm tahun 1982.

Kemudian, pada Jurnal Hukum RESPUBLICA Volume 9 Nomor 2 Tahun 2010, Budi Santoso menulis dengan judul "International CSR Standards dari Sudut Pandang Hukum Internasional". Menurutnya, aktivitas bisnis suatu perusahaan dapat menimbulkan dampak kepada orang lain, masyarakat, serta lingkungan tempat perusahaan tersebut beroperasi (Santoso, 2010: 216).

Sejalan dengan itu, pada Jurnal Hukum ILMU HUKUM Edisi I Nomor 1 Tahun 2010, Firdaus menulis dengan judul "Corporate Social Responsibility; Transformasi Moral ke dalam Hukum dalam Membangun Kesejahteraan Masyarakat". Menurutnya, Corporate Social Responsibility merupakan transformasi nilai moral menjadi kewajiban hukum. Kewajiban Corporate Social Responsibility bertujuan membangun kepedulian perusahaan pengelolaan sumber daya alam untuk berpartisipasi dalam mewujudkan kesejahteraan masyarakat (Firdaus, 2010: 27).

Pada Jurnal Hukum RESPUBLICA Volume 11 Nomor 1 Tahun 2011, Firdaus juga menulis dengan judul "Corporate Social Responsibility dalam Hak Asasi Manusia; Studi terhadap Pemenuhan Hak Ekonomi Sosial Masyarakat Lokal oleh Perusahaan Perkebunan Kelapa Sawit". Menurutnya, Corporate Social Responsibility merupakan konstruksi hukum negara untuk memberi jaminan agar pengelolaan sumber daya alam oleh perusahaan perkebunan kelapa sawit memberi kemakmuran bagi masyarakat (Firdaus, 2011: 12). Pada jurnal yang sama, Yetti menulis dengan judul "Implikasi Corporate Social Responsibility terhadap Aplikasi Undang-Undang Nomor 5 Tahun 1999". Menurutnya, penerapan Corporate Social Responsibility tidak lagi dianggap sebagai cost, tetapi sebagai investasi perusahaan, karena sesungguhnya perusahaan dan masyarakat memiliki saling ketergantungan yang tinggi (Yetti, 2011: 40-41).

Selanjutnya, pada Jurnal Hukum IUS Volume I Nomor 2 Tahun 2013, Lelisari Siregar dan Rahdian Ihsan menulis dengan judul "Penerapan Ketentuan Corporate Social Responsibility (CSR) pada Perusahaan Swasta". Menurutnya, Corporate Social Responsibility telah menjadi isu global, namun belum ada satu definisi tunggal dari 
Corporate Social Responsibility yang diterima secara global. Di Indonesia, konsep Corporate Social Responsibility semakin menguat terutama setelah dinyatakan dengan tegas dalam Undang-Undang Nomor 25 Tahun 2007 tentang Penanaman Modal dan Undang-Undang Nomor 40 Tahun 2007 tentang Perseroan Terbatas. Beberapa tahun terakhir memperlihatkan bahwa perusahaan telah melaksanakan Corporate Social Responsibility sebagai sebuah program yang wajib diimplementasikan. Dalam hal ini, keberhasilan sebuah daerah dalam memajukan dan menyejahterakan penduduknya hanya terwujud jika seluruh komponen masyarakat ikut ambil bagian, termasuk partisipasi real dari perusahaan yang beroperasi di wilayah tersebut (Siregar dan Ihsan, 2013: 221-222).

Selain itu, pada Jurnal Hukum Islam AHKAM Volume XIV Nomor 1 Tahun 2014, Yayan Sopyan menulis dengan judul "Corporate Social Responsibility (CSR) sebagai Implementasi Fikih Sosial untuk Pemberdayaan Masyarakat". Menurutnya, Corporate Social Responsibility merupakan tanggung jawab perusahaan dalam melakukan bina lingkungan. Corporate Social Responsibility dalam pandangan fikih sosial tidak hanya diposisikan sebagai kewajiban perusahaan, tetapi juga merupakan kewajiban sosial yang harus ada sebagai bagian dari hidup bermasyarakat. Pemerintah harus mendorong perusahaan dalam melaksanakan Corporate Social Responsibility dari voluntary (bersifat sukarela) menjadi mandatory (bersifat mengikat), sehingga eksistensi Corporate Social Responsibility dapat dirasakan lebih nyata oleh masyarakat (Sopyan, 2014: 53).

Apabila mencermati berbagai ulasan dalam tinjauan kepustakaan sebagaimana yang dijelaskan di atas, maka tidak ditemukan pembahasan mengenai implementasi Corporate Social Responsibility PT Riau Crumb Rubber Factory terhadap masyarakat Kelurahan Sri Meranti Kota Pekanbaru berdasarkan Peraturan Daerah Provinsi Riau Nomor 6 Tahun 2012 tentang Tanggung Jawab Sosial Perusahaan di Provinsi Riau. Kalaupun ada pembahasan mengenai implementasi Corporate Social Responsibility terhadap masyarakat yang bertempat tinggal di sekitar lokasi perusahaan, penelitian tersebut dilaksanakan di lokasi yang berbeda dengan penelitian ini.

\section{Implementasi Corporate Social Responsibility PT Riau Crumb Rubber Factory terhadap Masyarakat Kelurahan Sri Meranti Kota Pekanbaru}

PT Riau Crumb Rubber Factory adalah pabrik pengolahan bahan karet mentah menjadi bahan karet setengah jadi untuk bahan baku industri. Perusahaan ini mulai beroperasi di Kota Pekanbaru sejak tahun 1969, yang berkedudukan di Kelurahan Sri Meranti. Awalnya, perusahaan ini berdiri di atas lahan kosong berupa hutan di tepi Sungai Siak yang berada di pinggir kota. Akan tetapi, seiring dengan perkembangan dan kemajuan Kota Pekanbaru sebagai ibukota Provinsi Riau, saat ini Kelurahan Sri Meranti telah berubah menjadi kawasan padat penduduk. Data sensus penduduk tahun 2016 menunjukkan bahwa jumlah penduduk di Kelurahan Sri Meranti saat ini berjumlah 21.987 jiwa. 
Kegiatan produksi pengolahan bahan karet mentah menjadi bahan karet setengah jadi yang berlangsung secara terus-menerus di PT Riau Crumb Rubber Factory telah menyebabkan berbagai polusi yang berdampak bagi lingkungan dan masyarakat, seperti polusi udara dan polusi air. Pengolahan bahan karet mentah tersebut menimbulkan bau busuk yang menyengat yang mengganggu pernapasan masyarakat yang bertempat tinggal di sekitar lokasi perusahaan. Selain itu, Sungai Siak yang merupakan sumber air utama bagi masyarakat, airnya juga telah tercemar oleh limbah pabrik.

Seharusnya, perusahaan yang menjalankan kegiatan usahanya di bidang dan/atau berkaitan dengan sumber daya alam wajib melaksanakan tanggung jawab sosial dan lingkungan, dengan tujuan untuk menciptakan hubungan antara perusahaan dan masyarakat yang serasi, seimbang, dan sesuai dengan lingkungan, nilai, norma, dan budaya masyarakat setempat. Hal ini sebagaimana yang diamanatkan oleh Undang-Undang Nomor 40 Tahun 2007 tentang Perseroan Terbatas.

Kenyataannya, Corporate Social Responsibility yang dilaksanakan oleh PT Riau Crumb Rubber Factory sangat minim dirasakan oleh masyarakat Kelurahan Sri Meranti, khususnya bagi masyarakat yang bertempat tinggal di RW 02 Kelurahan Sri Meranti, tempat perusahaan tersebut berada. Hal ini tidak sebanding dengan polusi dan kerusakan lingkungan yang diakibatkan oleh kegiatan operasional perusahaan tersebut, yang dampaknya dirasakan langsung sehari-hari oleh masyarakat.

Selain itu, untuk dapat memperoleh dana Corporate Social Responsibility dari PT Riau Crumb Rubber Factory, masyarakat harus mengajukan proposal permohonan bantuan terlebih dahulu kepada perusahaan. Lalu, masyarakat diminta untuk menunggu proposal tersebut diproses hingga disetujui oleh perusahaan. Setelah proposal tersebut disetujui, barulah masyarakat menerima bantuan dana Corporate Social Responsibility dari perusahaan, yang ternyata jumlahnya tidak sesuai dengan yang diharapkan oleh masyarakat.

Sementara itu, mengenai peluang proposal permohonan bantuan disetujui oleh perusahaan, PT Riau Crumb Rubber Factory akan memprioritaskan proposal yang berasal dari masyarakat yang bertempat tinggal di sekitar lokasi perusahaan, seperti masyarakat Kelurahan Sri Meranti. Namun, tidak semua proposal permohonan bantuan yang diajukan oleh masyarakat tersebut akan disetujui, karena perusahaan ini lebih memprioritaskan menyalurkan dana Corporate Social Responsibility untuk fasilitas umum yang menjadi kebutuhan bersama oleh masyarakat, seperti bantuan untuk renovasi masjid.

PT Riau Crumb Rubber Factory telah menyediakan dana setiap tahunnya untuk melaksanakan Corporate Social Responsibility, namun tidak ada program khusus dari perusahaan. Perusahaan ini sifatnya hanya menunggu masyarakat untuk mengajukan proposal permohonan bantuan. Hal seperti ini seharusnya tidak terjadi 
karena Corporate Social Responsibility merupakan tanggung jawab hukum yang wajib dilaksanakan oleh PT Riau Crumb Rubber Factory kepada masyarakat Kelurahan Sri Meranti. Seharusnya, Corporate Social Responsibility dapat dilaksanakan dalam berbagai bentuk. Program tanggung jawab sosial perusahaan dapat berbentuk pemberdayaan masyarakat dan/atau kemitraan dan bina lingkungan dan/atau investasi dan/atau sumbangan/donasi, dan/atau promosi. Selanjutnya, bidang kerja tanggung jawab sosial perusahaan dapat dijalankan pada bidang pendidikan, kesehatan, infrastruktur, olahraga dan seni budaya, sosial dan keagamaan, pelestarian lingkungan hidup, usaha ekonomi kerakyatan, pemberdayaan masyarakat adat, serta bidang kerja lainnya yang secara nyata memberikan dampak peningkatan kualitas masyarakat.

Selain membantu masyarakat yang bertempat tinggal di sekitar lokasi perusahaan, PT Riau Crumb Rubber Factory juga menyalurkan dana Corporate Social Responsibility untuk membantu kegiatan yang diselenggarakan oleh pemerintah, seperti acara Musābaqah Tilāwatil Qur'ān (MTQ) tingkat Kecamatan Rumbai yang diadakan di Masjid Nurul 'Ilmi Kelurahan Sri Meranti. Akan tetapi, mengenai program Corporate Social Responsibility yang telah dilaksanakan, PT Riau Crumb Rubber Factory tidak pernah melaporkannya secara berkala kepada pemerintah, minimal kepada Lurah Sri Meranti.

\section{Hambatan-hambatan dalam Implementasi Corporate Social Responsibility PT Riau Crumb Rubber Factory terhadap Masyarakat Kelurahan Sri Meranti Kota Pekanbaru}

Sebagaimana telah disebutkan sebelumnya, program tanggung jawab sosial perusahaan dapat berbentuk pemberdayaan masyarakat dan/atau kemitraan dan bina lingkungan dan/atau investasi dan/atau sumbangan/donasi, dan/atau promosi. Selanjutnya, bidang kerja tanggung jawab sosial perusahaan dapat dijalankan pada bidang pendidikan, kesehatan, infrastruktur, olahraga dan seni budaya, sosial dan keagamaan, pelestarian lingkungan hidup, usaha ekonomi kerakyatan, pemberdayaan masyarakat adat, serta bidang kerja lainnya yang secara nyata memberikan dampak peningkatan kualitas masyarakat. Akan tetapi, ada beberapa hambatan, baik yang bersifat internal maupun eksternal, yang membuat PT Riau Crumb Rubber Factory tidak dapat memenuhi semua bidang yang menjadi kebutuhan masyarakat Kelurahan Sri Meranti seperti yang diamanatkan oleh Peraturan Daerah Provinsi Riau Nomor 6 Tahun 2012 tentang Tanggung Jawab Sosial Perusahaan di Provinsi Riau.

Hambatan internal yang mengambat pelaksanaan Corporate Social Responsibility oleh PT Riau Crumb Rubber Factory disebabkan karena perusahaan ini sedang dalam kondisi keuangan yang sulit sehingga terbatasnya anggaran dana Corporate Social Responsibility yang dianggarkan oleh perusahaan. Oleh karena itu, perusahaan ini lebih memprioritaskan menyalurkan dana Corporate Social 
Responsibility untuk fasilitas umum yang menjadi kebutuhan bersama oleh masyarakat, seperti bantuan untuk renovasi masjid.

Sebenarnya, Corporate Social Responsibility merupakan tanggung jawab hukum yang wajib dilaksanakan oleh PT Riau Crumb Rubber Factory kepada masyarakat Kelurahan Sri Meranti, sebagaimana yang diamanatkan oleh UndangUndang Nomor 40 Tahun 2007 tentang Perseroan Terbatas. Akan tetapi, minimnya pengetahuan hukum masyarakat Kelurahan Sri Meranti mengenai Corporate Social Responsibility menjadi hambatan eksternal, sehingga masyarakat beranggapan bahwa Corporate Social Responsibility hanya merupakan bantuan sukarela dari perusahaan kepada masyarakat. Selain itu, masyarakat Kelurahan Sri Meranti tidak ada yang mempermasalahkan mengenai minimnya dana Corporate Social Responsibility yang diberikan oleh PT Riau Crumb Rubber Factory untuk setiap proposal permohonan bantuan yang diajukan oleh masyarakat. Hal ini karena perusahaan ini selalu memprioritaskan untuk merekrut masyarakat Kelurahan Sri Meranti sebagai tenaga kerjanya. Bahkan, untuk level buruh pabrik, sekitar 75\% tenaga kerja perusahaan ini adalah masyarakat Kelurahan Sri Meranti. Menurut Manajer Personalia dan Humas PT Riau Crumb Rubber Factory, inilah salah satu bentuk tanggung jawab perusahaan terhadap masyarakat yang bertempat tinggal di sekitar lokasi perusahaan.

\section{Upaya Hukum terhadap Hambatan-hambatan dalam Implementasi Corporate Social Responsibility PT Riau Crumb Rubber Factory terhadap Masyarakat Kelurahan Sri Meranti berdasarkan Peraturan Daerah Provinsi Riau Nomor 6 Tahun 2012 tentang Tanggung Jawab Sosial Perusahaan di Provinsi Riau}

Menurut Undang-Undang Nomor 40 Tahun 2007 tentang Perseroan Terbatas, perseroan yang menjalankan kegiatan usahanya di bidang dan/atau berkaitan dengan sumber daya alam wajib melaksanakan tanggung jawab sosial dan lingkungan. Dalam undang-undang tersebut tidak ada disebutkan secara jelas sanksi bagi perusahaan yang tidak melaksanakan Corporate Social Responsibility. UndangUndang Nomor 40 Tahun 2007 hanya menyebutkan bahwa perseroan yang tidak melaksanakan tanggung jawab sosial dan lingkungan dikenai sanksi sesuai dengan ketentuan peraturan perundang-undangan.

Peraturan Daerah Provinsi Riau Nomor 6 Tahun 2012 tentang Tanggung Jawab Sosial Perusahaan di Provinsi Riau sebagai landasan hukum pelaksanaan corporate social responsibility bagi perusahaan-perusahaan yang beroperasi di wilayah Provinsi Riau mengatur mengenai adanya sanksi apabila ada perusahaan yang tidak melaksanakan Corporate Social Responsibility, yaitu berupa sanksi administrasi dari pemerintah terhadap perusahaan. Oleh karena itu, apabila PT Riau Crumb Rubber Factory tidak melaksanakan Corporate Social Responsibility, maka masyarakat Kelurahan Sri Meranti dapat menyampaikan aspirasinya kepada Dewan Perwakilan Rakyat Daerah (DPRD) Provinsi Riau sebagai lembaga yang mengawasi 
pelaksanaan peraturan daerah agar perusahaan tersebut direkomendasikan mendapat sanksi administratif dari Pemerintah Provinsi Riau, seperti pembekuan izin operasional perusahaan.

Berdasarkan Peraturan Daerah Provinsi Riau Nomor 6 Tahun 2012, setiap perusahaan harus memberikan laporan pelaksanaan Corporate Social Responsibility sekurang-kurangnya sekali dalam setahun kepada Pemerintah Provinsi Riau, yang meliputi:

a. Realisasi pelaksanaan tanggung jawab sosial perusahaan

b. Realisasi penggunaan biaya tanggung jawab sosial perusahaan

c. Capaian kinerja pelaksanaan tanggung jawab sosial perusahaan

d. Permasalahan yang dihadapi dan upaya pemecahannya

e. Rencana tindak lanjut

\section{KESIMPULAN}

Berdasarkan hasil pembahasan mengenai Corporate Social Responsibility oleh PT Riau Crumb Rubber Factory terhadap masyarakat Kelurahan Sri Meranti Kota Pekanbaru, maka dapat disimpulkan beberapa hal sebagai berikut:

1. Implementasi corporate social responsibility PT Riau Crumb Rubber Factory terhadap masyarakat Kelurahan Sri Meranti Kota Pekanbaru adalah PT Riau Crumb Rubber Factory telah melaksanakan Corporate Social Responsibility, namun belum memenuhi harapan masyarakat Kelurahan Sri Meranti karena tidak sebanding dengan polusi dan kerusakan lingkungan yang diakibatkan oleh kegiatan operasional perusahaan. Harus ada hubungan saling menguntungkan, baik kepentingan perusahaan maunpun kepentingan masyarakat. Untuk itulah, seharusnya, PT Riau Crumb Rubber Factory harus mau menjemput bola tanpa perlu menunggu pengajuan dari masyarakat.

2. Hambatan-hambatan dalam implementasi Corporate Social Responsibility PT Riau Crumb Rubber Factory terhadap masyarakat Kelurahan Sri Meranti Kota Pekanbaru dari sisi internal perusahaan adalah terbatasnya anggaran dana Corporate Social Responsibility yang dimiliki oleh PT Riau Crumb Rubber Factory untuk dapat memenuhi semua kebutuhan masyarakat, sedangkan dari sisi masyarakat adalah minimnya pengetahuan hukum masyarakat Kelurahan Sri Meranti mengenai Corporate Social Responsibility.

3. Upaya hukum untuk mengatasi hambatan-hambatan dalam implementasi corporate social responsibility PT Riau Crumb Rubber Factory terhadap masyarakat Kelurahan Sri Meranti berdasarkan Peraturan Daerah Provinsi Riau Nomor 6 Tahun 2012 tentang Tanggung Jawab Sosial Perusahaan di Provinsi Riau adalah apabila PT Riau Crumb Rubber Factory tidak melaksanakan corporate social responsibility, maka masyarakat Kelurahan Sri Meranti dapat menyampaikan aspirasinya kepada Dewan Perwakilan Rakyat Daerah (DPRD) Provinsi Riau agar perusahaan tersebut direkomendasikan mendapat sanksi administratif dari Pemerintah Provinsi Riau, seperti pembekuan izin operasional perusahaan. 


\section{DAFTAR PUSTAKA}

\section{a. Buku}

Adjie, Habib (2008). Status Badan Hukum, Prinsip-prinsip, dan Tanggung Jawab Sosial Perseroan Terbatas. Bandung: Mandar Maju.

Fahmi (2015). Pergeseran Tanggung Jawab Sosial Perseroan, dari Tanggung Jawab Moral ke Tanggung Jawab Hukum. Yogyakarta: FH UII Press.

H.S., Salim dan Erlies Septiana Nurbani (2016). Penerapam Teori Hukum pada Penelitian Disertasi dan Tesis. Jakarta: Rajawali Pers.

Khairandy, Ridwan (2009). Perseroan Terbatas; Doktrin, Peraturan Perundangundangan, dan Yurisprudensi. Yogyakarta: Kreasi Total Media.

Prasetya, Rudhi (2011). Perseroan Terbatas: Teori dan Praktik, Jakarta, Sinar Grafika. Untung, Hendrik Budi (2009). Corporate Social Responsibility. Jakarta: Sinar Grafika. Wahyudi, Isra dan Busyro Azheri (2008). Corporate Social Responsibility; Prinsip, Pengaturan, dan Implementasi. Malang: In-Trans.

\section{b. Jurnal}

Ferdi (2009). Aspek Hukum Internasional dalam Pengaturan Tanggung Jawab Sosial Perusahaan (Corporate Social Responsibility). Jurnal Hukum Respublica, 8(2).

Firdaus (2010). Corporate Social Responsibility; Transformasi Moral ke dalam Hukum dalam Membangun Kesejahteraan Masyarakat. Jurnal Hukum Ilmu Hukum, 1(1).

(2011). Corporate Social Responsibility dalam Hak Asasi Manusia; Studi terhadap Pemenuhan Hak Ekonomi Sosial Masyarakat Lokal oleh Perusahaan Perkebunan Kelapa Sawit. Jurnal Hukum Respublica, 11(1).

Jayakusuma, Zulfikar (2007). Tanggung Jawab Sosial Perusahaan Transnasional Pertambangan Minyak terhadap Masyarakat Lokal (Perspektif Hak Asasi Manusia). Jurnal Hukum Respublica, 7(1).

Santoso, Budi (2010). International CSR Standards dari Sudut Pandang Hukum Internasional. Jurnal Hukum Respublica, 9(2).

Sembiring, Sentosa (2009). Tanggung Jawab Sosial dan Lingkungan (Corporate Social and Environment Responsibilities) dalam Perspektif Hukum Perusahaan. Jurnal Hukum Yustisia, 77(20).

Siregar, Lelisari dan Rahdian Ihsan (2013). Penerapan Ketentuan Corporate Social Responsibility (CSR) pada Perusahaan Swasta. Jurnal Hukum Ius, 1(2).

Sopyan, Yayan (2014). Corporate Social Responsibility (CSR) sebagai Implementasi Fikih Sosial untuk Pemberdayaan Masyarakat. Jurnal Hukum Islam Ahkam, 16(1).

Yetti (2007). Tanggung Jawab Perusahaan terhadap Sosial dan Lingkungan Berdasarkan Undang-Undang Nomor 40 Tahun 2007 tentang Perseroan Terbatas. Jurnal Hukum Respublica, 7(1).

(2011). Implikasi Corporate Social Responsibility terhadap Aplikasi UndangUndang Nomor 5 Tahun 1999. Jurnal Hukum Respublica, 11(1). 